\title{
Effect of climate change on Aspergillus flavus and aflatoxin $\mathrm{B}_{1}$ production
}

\author{
Angel Medina, Alicia Rodriguez and Naresh Magan* \\ Applied Mycology Group, Cranfield Soil and AgriFood Institute, Cranfield University, Cranfield, Bedford, UK
}

\section{Edited by:}

Mehdi Razzaghi-Abyaneh, Pasteur

Institute of Iran, Iran

\section{Reviewed by:}

Paula Cristina Azevedo Rodrigues, Polytechnic Institute of Braganca, Portugal

Russell Paterson, University of Minho, Portugal

\section{*Correspondence}

Naresh Magan, Applied Mycology Group, Cranfield Soil and AgriFood Institute, School of Applied Science, Cranfield University, Vincent

Building, College Road, Cranfield, Bedford MK43 OAL, UK

e-mail:n.magan@cranfield.ac.uk
This review considers the available information on the potential impact of key environmental factors and their interactions on the molecular ecology, growth and aflatoxin production by Aspergillus flavus in vitro and in maize grain. The recent studies which have been carried out to examine the impact of water activity $\times$ temperature on aflatoxin biosynthesis and phenotypic aflatoxin production are examined. These have shown that there is a direct relationship between the relative expression of key regulatory and structural genes under different environmental conditions which correlate directly with aflatoxin B1 production. A model has been developed to integrate the relative expression of 10 biosynthetic genes in the pathway, growth and aflatoxin $B_{1}\left(A F B_{1}\right)$ production which was validated under elevated temperature and water stress conditions. The effect of interacting conditions of $\mathrm{a}_{\mathrm{w}} \times$ temperature $\times$ elevated $\mathrm{CO}_{2}(2 \times$ and $3 \times$ existing levels) are detailed for the first time. This suggests that while such interacting environmental conditions have little effect on growth they do have a significant impact on aflatoxin biosynthetic gene expression (structural afID and regulatory afl $R$ genes) and can significantly stimulate the production of $A F B_{1}$. While the individual factors alone have an impact, it is the combined effect of these three abiotic factors which have an impact on mycotoxin production. This approach provides data which is necessary to help predict the real impacts of climate change on mycotoxigenic fungi.

Keywords: climate change factors, water activity, temperature, elevated $\mathrm{CO}_{2}$, growth, gene expression, aflatoxin production, ecology

\section{INTRODUCTION}

Food security has become a very important issue world-wide and the potential effects of climate change on yields and quality of food is now receiving significant attention by scientists, especially from a risk analysis perspective. The moldy contamination of staple foods such as cereals has received attention because of their acute and chronic effects in humans and animals. Indeed, the increasing use of staple crops, especially maize for biofuel production, has put further pressure on such key food crops. There is particular interest in maize because it is a key staple food in both developed and developing regions world-wide. Maize is prone to infection by Aspergillus flavus and Aspergillus parasiticus, especially via insect damage during silking and contamination with aflatoxins. Aflatoxins have been rated as class 1A carcinogens by the International Agency for Research of Cancer (IARC, 2012). They are heat stable and difficult to destroy during processing. Thus exposure, both acute and chronic, can have significant impacts on vulnerable groups, especially babies and children. This has resulted in strict legislative limits in many parts of the world for aflatoxins and mycotoxins in a wide range of foodstuffs (European Commission., 2006). However, in African countries where legislation is often applied to export crops only, consumption of mycotoxin contaminated staple foods is a significant risk, with rural populations exposed to aflatoxins throughout their lives, with serious impacts on their health (Wagacha and
Muthomi, 2008). This is exemplified by the relatively recent acute outbreak of severe aflatoxicosis in Kenya (Lewis et al., 2005).

Climate change is expected to have a profound effect on our landscape world-wide. For some areas, climatic models have projected a marked decrease in summer precipitation and increases in temperature, which would result in concomitant drought stress episodes. The environment in which crops will be grown in the next 10-25 years may change markedly with atmospheric $\mathrm{CO}_{2}$ concentrations expected to double or triple (from 350 to 700 or $900-1000 \mathrm{ppm})$. Thus, there has been a lot of interest in the impact that climate change scenarios may have on economically important crops/mycotoxigenic fungal infection and contamination with mycotoxins (Paterson and Lima, 2010, 2011; Magan et al., 2011; Wu et al., 2011). Indeed, climate change conditions may impact on the interactions between different mycotoxigenic species and indeed other mycobiota and determine the relative mycotoxin composition contaminating staple foods/feeds (Magan et al., 2010; Paterson and Lima, 2012). Because of this increase and that of other greenhouse gases, the global temperature is expected to increase by between +2 and $+5^{\circ} \mathrm{C}$.

The EU green paper on climate change in Europe also suggests that effects will be regional and be either detrimental or advantageous depending on geographical area. Thus, in Southern Europe, changes may equate to an increase of $4-5^{\circ} \mathrm{C}$ with longer drought periods, resulting in increasing desertification, and a 
decrease in crop yields. In areas of Western and Atlantic Europe, changes of $2.5-3.5^{\circ} \mathrm{C}$ with dryer and hotter summers are envisaged. In Central Europe, an increase of $3-4^{\circ} \mathrm{C}$, higher rainfall and floods are forecast, although longer growing periods may benefit crop yields. Northern Europe would expect a mean temperature increase of $3-4.5^{\circ} \mathrm{C}$, with a significant increase in precipitation of $30-40 \%$. This may lead to increases in crop yields and perhaps new crop cultivation patterns (European Commission., 2007; Solomon et al., 2007). Similar impacts have been described in other areas of the world, especially parts of Asia and Central and South America which are important producers of staple crops (IPCC, 2007). A recent study has predicted that, on a global scale, pests, and diseases are moving to the poles at the rate of $3-5 \mathrm{~km}$ /year (Bebber et al., 2013). This could have further impacts on contamination of staple foods such as maize, as increases in pest reproduction rates will lead to more damage and facilitate more infection by $A$. flavus and contamination with aflatoxins. However, in the recent predictions by Bebber et al. (2013) no focus on spread of mycotoxigenic fungi or mycotoxins or interactions between pathogens and pests were considered in the context of climate change.

In developing countries drought stress may be particularly important in terms of food security. For example, marginal land where stress tolerant sorghum was previously grown has now been replaced with maize in both West and East Africa. Maize as well as ground nuts are particularly prone to infection when water stress periods occur. This leads to increased aflatoxin contamination of such crops pre-harvest and post-harvest and can significantly impact on the ability to export the crop and also on the nutritional quality when consumed in rural subsistence communities.

Magan et al. (2011) suggested that climate change factors may result in xerophilic fungi such as Wallemia sebi, Xeromyces bisporus, and Chrysosporium species becoming more important as colonizers of food commodities, as they can grow under very dry conditions [0.65-0.75 water activity $\left(\mathrm{a}_{\mathrm{w}}\right)$ ] where there is much less competition from the majority of mesophilic fungi (Magan, 2006; Magan and Aldred, 2007). For example, W. sebi can produce metabolites such as walleminol and walleminone which can be toxic to animals and humans (Piecková and Kunová, 2002). Studies also suggest that there are competitive interactions between these xerophilic fungi in dry and hot conditions and that secondary metabolites may play a role (Leong et al., 2010). This will certainly have an impact on agricultural productivity, especially of essential/staple food crops such as maize and nuts and also influence the interface between plants, insect pests and fungal infection of staple foods (Miraglia et al., 2009). This could have a profound effect on pre- and post-harvest mycotoxin contamination, especially aflatoxins in developing countries, where food quality and security issues are critical.

Examples of modified weather regimes impacting on mycotoxins were demonstrated by the 2003/2004 and subsequently in 2012 summer seasons in the Mediterranean region such as Northern Italy where drought and elevated temperatures resulted in a switch from Fusarium verticillioides and contamination with fumonisins to significant contamination of maize grain with A. flavus and aflatoxins and entry of aflatoxin $\mathrm{M}_{1}$ into the dairy chain via the animal feed chain (Giorni et al., 2007). More recently, a survey of Serbian maize samples in 2009-2011 contained no aflatoxins. However, prolonged hot and dry weather in 2012 resulted in $69 \%$ of samples containing aflatoxins (Kos et al., 2013). Similarly in Hungary it has also been shown that an increase in aflatoxins may be due to climate change conditions (Dobolyi et al., 2013). However, previous to these examples there are only a few concrete examples of such incidences where climate change factors have been implicated (Magan et al., 2011).

\section{EFFECT OF WATER STRESS $\times$ TEMPERATURE STRESS EFFECTS ON AFLATOXIN CLUSTER GENE EXPRESSION, GROWTH, AND AFLATOXIN PRODUCTION}

Generally, the aflatoxin biosynthesis genes of A. flavus and A. parasiticus are highly homologous and the order of the genes (approx. 30) within the cluster has been shown to be the same (Yu et al., 1995, 2004). These include key regulatory genes (aflR and aflS) and a series of up and downstream structural genes. It has been shown that both water availability and temperature modifications affect the expression of these clusters of genes, relative growth rate and aflatoxin production in both $A$. flavus and A. parasiticus (Schmidt-Heydt et al., 2010, 2011). It was shown that there was a good correlation between the expression of an early structural gene $(a f l D)$ and aflatoxin $\mathrm{B}_{1}\left(\mathrm{AFB}_{1}\right)$ (Abdel-Hadi et al., 2010). It has also been shown that temperature $\times a_{w}$ interactions were related to the ratio of the two key regulatory genes (aflR/aflS). The higher the ratio, the higher the relative $\mathrm{AFB}_{1}$ production (Schmidt-Heydt et al., 2009, 2010; Figure 1). This suggests that under certain interacting conditions of two environmental stress factors significantly influences on the relative amounts of $\mathrm{AFB}_{1}$ produced.

The study by Abdel-Hadi et al. (2010) also showed that when examining the relationship between temporal $\mathrm{AFB}_{1}$ production and the relative expression of the aflD structural gene involved early in the biosynthetic pathway then the relative expression could be mapped over time (Figure 2). This also suggests that the optimum $\mathrm{a}_{\mathrm{w}}$ for aflD expression was at $0.90 \mathrm{a}_{\mathrm{w}}$, which is different from that for growth $\left(0.95 \mathrm{a}_{\mathrm{w}}\right)$.

More recent detailed studies using a mycotoxin microarray (Schmidt-Heydt and Geisen, 2007) have been useful in elucidating the relationship between both key structural genes and the regulatory genes and interacting conditions of $\mathrm{a}_{\mathrm{w}} \times$ temperature and integrated the data on relative expression of 10 genes with growth and $\mathrm{AFB}_{1}$ data (Abdel-Hadi et al., 2012). Figure 3 shows the effect of these factors on growth and $\mathrm{AFB}_{1}$ production. They were able to model and validate this relationship under elevated temperature and drought stress conditions but elevated $\mathrm{CO}_{2}$ was not included in these studies. However, the relative relationship between the regulatory genes and key structural genes were examined using relative expression data under conditions of changing temperature and water stress to better understand the relationships between the regulatory and structural genes (Figure 4). This development of such ternary diagrams can help to evaluate the relationships between 3 key regulatory and structural genes at a time under different temperature and water stress conditions to help identify which are critical in the biosynthetic pathway as environmental factors change. 


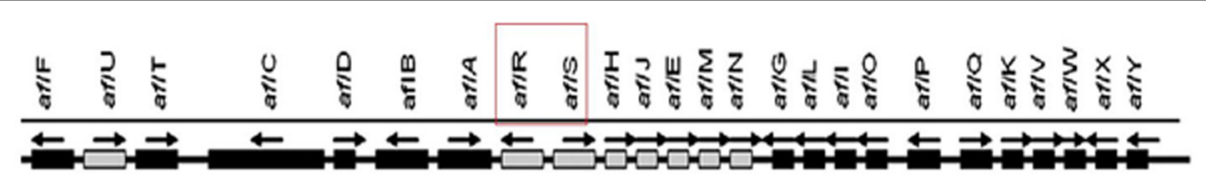

$\begin{aligned} & \text { Ratio of } \boldsymbol{a f l S} / \boldsymbol{a f l R} \text { in relation to aflatoxin biosynthesis and } \\ & \text { different parameter combinations }\end{aligned}$
$\begin{array}{lll}\text { Parameter combination } & \text { Ratio aflS/aflR } & \text { Aflatoxin }[\mathrm{ng} / \mathrm{g}] \\ 25^{\circ} \mathrm{C} / 0.90 & 0.5 & 3.7 \\ 35^{\circ} \mathrm{C} / 0.90 & 0.3 & 4.7 \\ 25^{\circ} \mathrm{C} / 0.95 & 7.4 & 830.2 \\ 30^{\circ} \mathrm{C} / 0.95 & 7.1 & 3016.9 \\ 25^{\circ} \mathrm{C} / 0.99 & 1.5 & 1957.3 \\ 30^{\circ} \mathrm{C} / 0.99 & 2.7 & 2758.7\end{array}$

FIGURE 1 | The key structural and regulatory genes involved in aflatoxin production and the effect of temperature $x$ water activity conditions, ratio of the two regulatory genes and relative amounts of aflatoxin $B_{1}$ production (adapted from Schmidt-Heydt et al., 2010).

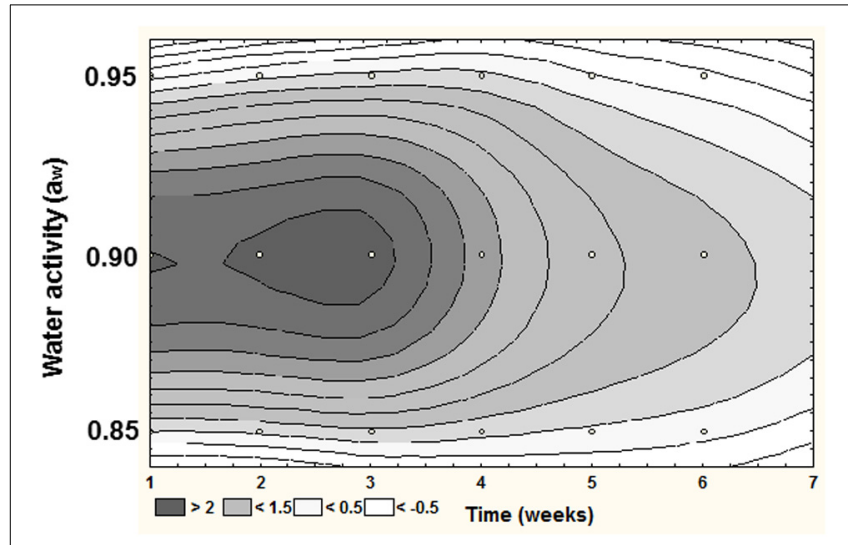

FIGURE 2 | Relative expression of afID (nor1) gene during colonization of peanuts by Aspergillus flavus during storage. Optimum expression occurred at $0.90 a_{w}$ during the first $2-3$ weeks of storage at $25^{\circ} \mathrm{C}$ (from Abdel-Hadi et al., 2010).

Schmidt-Heydt et al. (2008) also demonstrated that there was a stimulation of toxin biosynthetic gene expression in different mycotoxigenic fungi when exposed to interacting $a_{w} \times$ temperature stresses including A. flavus. They suggested that there was two peaks of expression one under optimum abiotic interacting conditions and one when water and temperature stress was applied. Studies by Yu et al. (2011) examined the effect of elevated temperature on the relative expression of the whole genome of a type strain of A. flavus to identify groups of up and down regulated genes. However, these studies were carried out over short time periods and did not include interactions with environmental stresses or with elevated $\mathrm{CO}_{2}$.

A significant amount of data exists on the effect of interactions between water availability and temperature on the life cycle of mycotoxigenic fungi and mycotoxin production (Sanchis and

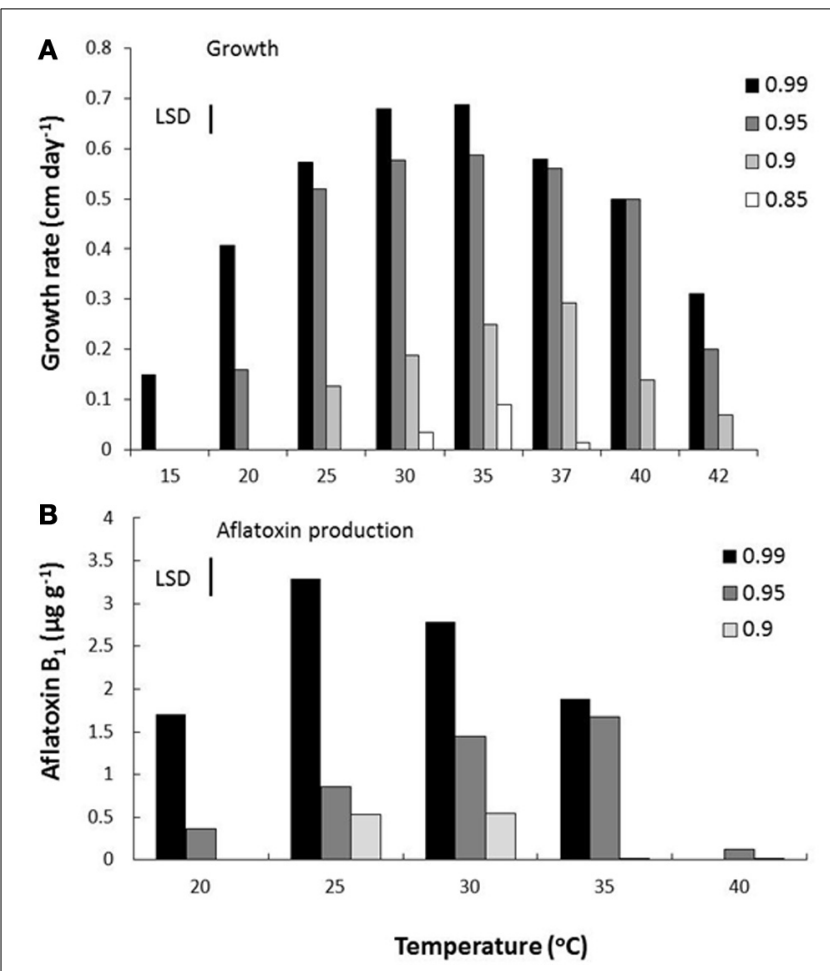

FIGURE 3 | Effect of water activity and temperature on (A) growth and (B) aflatoxin $B_{1}$, production by a strain of $\boldsymbol{A}$. flavus (Abdel-Hadi et al., 2012). Bars indicate least Significant Differences.

Magan, 2004; Magan and Aldred, 2007). This includes the ecological conditions of $\mathrm{a}_{\mathrm{w}} \times$ temperature which will facilitate growth and $\mathrm{AFB}_{1}$ production. The $\mathrm{a}_{\mathrm{w}} \times$ temperature boundary conditions for toxin production are slightly different from that for growth. Based on this information it is possible to predict the effect of increased temperature (e.g., $37^{\circ} \mathrm{C}$ ) and water stress 


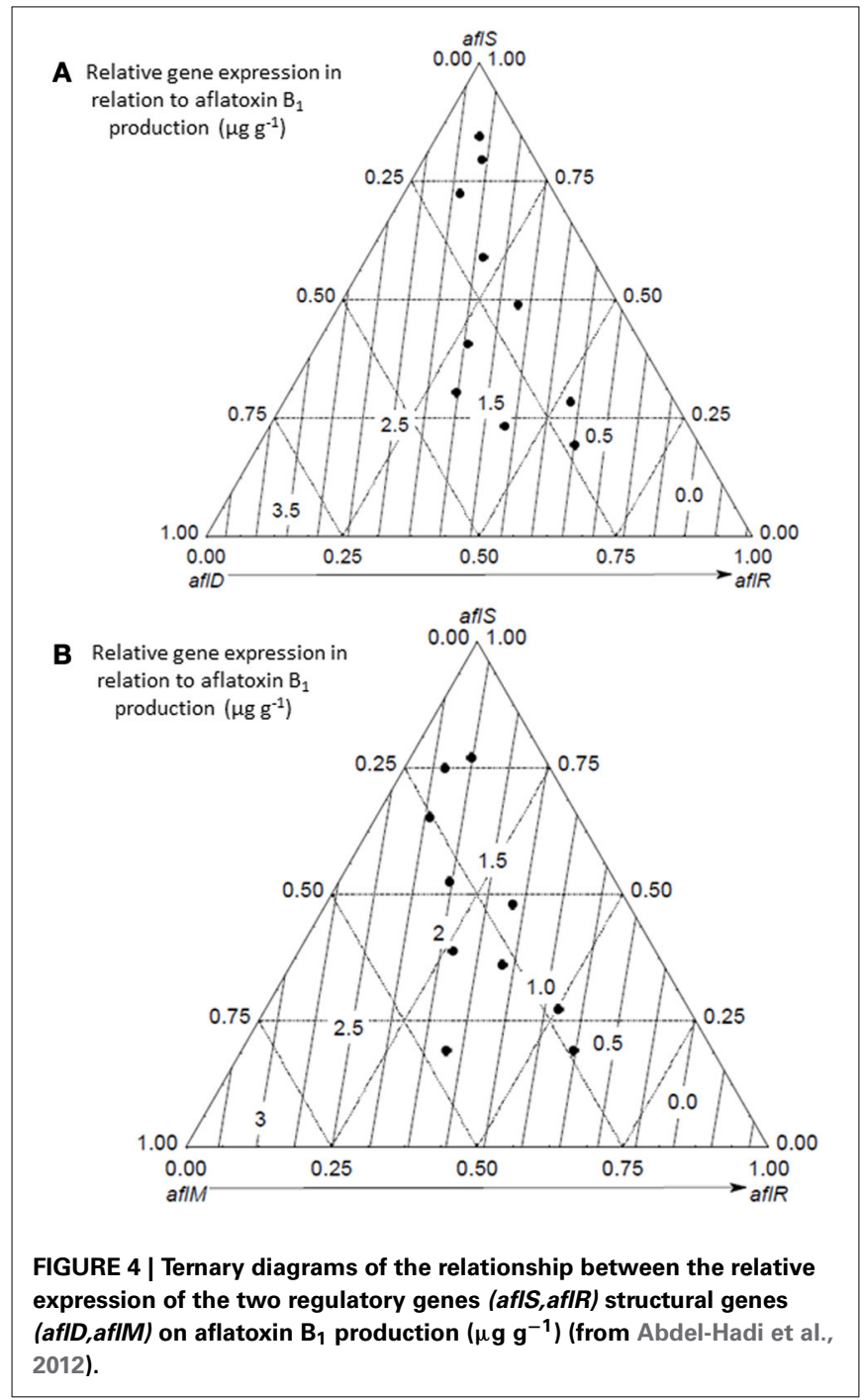

$\left(0.95,0.90 \mathrm{a}_{\mathrm{w}}\right)$ on growth and aflatoxin production (Table 1). This shows that as you increase the temperature to $37^{\circ} \mathrm{C}$ you get significantly less $\mathrm{AFB}_{1}$ produced although the $A$. flavus is able to grow. However, this excludes the interaction with $\mathrm{CO}_{2}$ which is necessary to examine in more detail the impact of predicted climate change scenarios.

\section{CLIMATE CHANGE IMPACTS $\left(\mathrm{a}_{\mathrm{w}} \times\right.$ TEMPERATURE $\left.\times \mathrm{CO}_{2}\right)$ ON AFLATOXIN GENE CLUSTER EXPRESSION, GROWTH AND TOXIN PRODUCTION}

Recently, Medina et al. (in press) examined the effect of existing environmental conditions and when conditions were changed from 34 to $37^{\circ} \mathrm{C}$, with drought stress and $\mathrm{CO}_{2}$ was increased to 650 and $1000 \mathrm{ppm}$. They examined the effects on growth of $A$. flavus and on the relative expression of the structural $a f l D$ and the regulatory aflR genes, as well as $A_{F B}$ production for the first time. These studies have shown that for growth of A. flavus there was relatively little effect of these interacting climate change conditions (Table 2). However, there were significant differences between growth in
Table 1 | Changes in growth and toxin production by Aspergillus flavus due to increase in temperature by +3 and $+5^{\circ} \mathrm{C}$ at different water stress conditions.

\begin{tabular}{|c|c|c|c|c|c|c|c|}
\hline \multicolumn{4}{|c|}{ Growth } & \multicolumn{4}{|c|}{ Aflatoxin $B_{1}$ production } \\
\hline$a_{w}$ & $\begin{array}{c}\mu \max \\
\text { range/T }\end{array}$ & $\mu+3$ & $\mu+5$ & $a_{w}$ & $\begin{array}{c}\tau \max \\
\operatorname{range} / \mathrm{T}\end{array}$ & $\tau+3$ & $\tau+5$ \\
\hline 0.95 & $6.9 / 35$ & 5.6 & 5.0 & 0.95 & $3082-2278 / 37$ & $102-138$ & 6.1-NP \\
\hline 0.90 & $2.9 / 37$ & 1.4 & 0.7 & 0.90 & $448.5-331.5 / 37$ & 1-NP & NP \\
\hline
\end{tabular}

Key: $\mu$ max, Maximum growth rate $\left(\mathrm{mm}\right.$ day $\left.^{-1}\right) ; \mu+3$, Growth rate increasing $3^{\circ} \mathrm{C} ; \mu+5$, Growth rate increasing $5^{\circ} \mathrm{C} ; \tau$ max, Maximum toxin production ( $\mu \mathrm{g}$ $\left.g^{-1}\right) ; \tau+3^{\circ} \mathrm{C}$, Predicted toxin increasing $+3^{\circ} \mathrm{C} ; \tau+5^{\circ} \mathrm{C}$, Predicted toxin increasing $+5^{\circ} \mathrm{C}, \mathrm{NP}$, No toxin production.

Table 2 | Comparison of growth of Aspergillus flavus under different interacting conditions of elevated temperature, drought stress, and elevated $\mathrm{CO}_{2}$ in vitro on a conductive yeast-glucose medium (adapted from Medina et al., in press).

\begin{tabular}{|c|c|c|c|c|c|c|c|}
\hline \multirow[b]{2}{*}{ Temperature } & & \multicolumn{6}{|c|}{ Diametric growth (mm/day) } \\
\hline & & \multicolumn{3}{|c|}{$34^{\circ} \mathrm{C}$} & \multicolumn{3}{|c|}{$37^{\circ} \mathrm{C}$} \\
\hline Water activity & & 0.97 & 0.95 & 0.92 & 0.97 & 0.95 & 0.92 \\
\hline \multirow[t]{3}{*}{ Carbon dioxide (ppm) } & 350 & 12.4 & 11.7 & 6.8 & 10.2 & 9.8 & 7.3 \\
\hline & 650 & 12.1 & 11.6 & 6.9 & 11.3 & 10.7 & 7.8 \\
\hline & 1000 & 12.1 & 11.3 & 6.3 & 10.9 & 10.5 & 7.8 \\
\hline
\end{tabular}

This was compared with the effect of these three-way interactions on the relative expression of both a structural gene and a regulatory gene (afID, afIR) in modified $a_{w} \times$ temperature $\times 650$ and $1000 p p m \mathrm{CO}_{2}$.

relation to $\mathrm{a}_{\mathrm{w}}$, but no effect of $\mathrm{a}_{\mathrm{w}} \times$ temperature $\times \mathrm{CO}_{2}$ on growth rate.

Table 3 summarizes the results of this study and shows the effects of the three-way interacting conditions on relative gene expression (aflD, aflR) and $\mathrm{AFB}_{1}$ production. This clearly shows that under slightly elevated $\mathrm{CO}_{2}$ conditions there was a stimulation of $\mathrm{AFB}_{1}$ production, especially under drought stress at $37^{\circ} \mathrm{C}$ and 650 and $1000 \mathrm{ppm} \mathrm{CO}_{2}$ exposure. It seems that the interactions between these three factors together are critical in the impact that slightly elevated $\mathrm{CO}_{2}$ has. This is clear from the results obtained at 0.92 and $0.95 \mathrm{a}_{\mathrm{w}} \times 37^{\circ} \mathrm{C}$ and 650 or $1000 \mathrm{ppm} \mathrm{CO}_{2}$ where a statistically significant increase in $\mathrm{AFB}_{1}$ was observed.

\section{DISCUSSION AND CONCLUSIONS}

This review has considered the impact of different key environmental factors on the growth, gene expression and $\mathrm{AFB}_{1}$ production by $A$. flavus. This has shown that while there are some examples of the impact that changes in climatic weather conditions may have resulted in a switch with contamination from fumonisins to aflatoxins in maize, there have been few studies to examine the three-way interactions of the key environmental factors. Previous studies have examined water stress $\times$ temperature interactions on relative biosynthetic genes involved in aflatoxin production and that by other mycotoxigenic fungi 
Table 3 | Summary of the impact that interactions between the three climate change variables have on relative expression of the structural and regulatory genes (afID, afIR), and aflatoxin $B_{1}$ production (from Medina et al., in press).

\begin{tabular}{|c|c|c|c|c|c|}
\hline $\begin{array}{l}\text { Temperature } \\
\left({ }^{\circ} \mathrm{C}\right)\end{array}$ & $a_{w}$ & $\begin{array}{c}\mathrm{CO}_{2} \\
(\mathrm{ppm})\end{array}$ & afID & afIR & $\mathrm{AFB}_{1}$ \\
\hline \multirow[t]{6}{*}{34} & 0.97 & 650 & $=$ & $=$ & $=$ \\
\hline & & 1000 & $=$ & $=$ & $=$ \\
\hline & 0.95 & 650 & $=$ & $=$ & $=$ \\
\hline & & 1000 & $=$ & $\uparrow(\times 3.6)$ & $=$ \\
\hline & 0.92 & 650 & $=$ & $\uparrow \uparrow(\times 24.4)$ & $\uparrow(\times 2.6)$ \\
\hline & & 1000 & $=$ & $\uparrow(\times 2.0)$ & $\uparrow(\times 2.0)$ \\
\hline \multirow[t]{6}{*}{37} & 0.97 & 650 & $\uparrow(\times 4.6)$ & $=$ & $\uparrow \uparrow(\times 30.7)$ \\
\hline & & 1000 & $\uparrow(\times 6.5)$ & $=$ & $\uparrow \uparrow(\times 23.8)$ \\
\hline & 0.95 & 650 & $\uparrow(\times 6.4)$ & $\uparrow \uparrow(\times 14.6)$ & $\uparrow \uparrow \uparrow(\times 79.2)$ \\
\hline & & 1000 & $\uparrow(\times 3.2)$ & $\uparrow \uparrow(\times 43.9)$ & $\uparrow \uparrow \uparrow(\times 78.5)$ \\
\hline & 0.92 & 650 & $=$ & $\uparrow \uparrow(\times 40.4)$ & $\uparrow \uparrow(\times 15.1)$ \\
\hline & & 1000 & $\uparrow \uparrow(\times 22.5)$ & $\uparrow \uparrow \uparrow(\times 1680)$ & $\uparrow \uparrow(\times 23.8)$ \\
\hline
\end{tabular}

$=$, variation lower than 2-fold. Numbers between brackets refer to the foldvariation with respect to the control.

(Abdel-Hadi et al., 2010; Schmidt-Heydt et al., 2010; Medina et al., 2013). However, there has been little detailed evidence of the impact that three-way interacting factors may impact on aflatoxin production.

The recent study by Medina et al. (in press) is the first to attempt to quantify the effects of interacting factors of water stress $\times$ temperature $\times$ elevated $\mathrm{CO}_{2}$ on growth, biosynthetic gene expression and $\mathrm{AFB}_{1}$ production. This new study suggests that when the three climate change factors are interacting there are responses which are not obtained when examining $\mathrm{a}_{\mathrm{w}} \times$ temperature conditions only. Thus, while growth is relatively unaffected by the addition of $2 \times$ and $3 \times$ existing $\mathrm{CO}_{2}$ levels at $37^{\circ} \mathrm{C}$ under the different water stress treatments used, this is not the case with mycotoxin production. The relative increased expression of both the structural aflD and the regulatory aflR genes in this recent study suggests that there is a significant impact on the biosynthetic genes involved in secondary metabolite production by strains of $A$. flavus. This was especially so at $37^{\circ} \mathrm{C}$ and under water stress $\left(0.95,0.92 \mathrm{a}_{\mathrm{w}}\right)$ where more changes were observed. This study showed that there is a strong stimulation of mycotoxin production (from $\times 15.1$ to $\times 79.2$ depending on the climate exposure conditions used).

Additional studies are now required to evaluate whether this is a general stress response or whether the presence of elevated $\mathrm{CO}_{2}$ results in its incorporation into the biosynthetic pathways for enzyme production and secondary metabolite production. Perhaps new studies need to be carried out with the cell wall integrity (CWI) and high-osmolarity glycerol (HOG) pathways to examine whether they are triggered by stimuli of the three interacting factors of water stress $\times$ temperature $\times$ elevated $\mathrm{CO}_{2}$ or if this is a general stress response per se (Hayes et al., 2014). Work is in progress with maize grain to compliment the data obtained by Medina et al. (in press). A recent study by Vaughan et al. (2014) showed that twice the existing $\mathrm{CO}_{2}$ concentrations (400 and $800 \mu \mathrm{mol} \mathrm{CO} \mathrm{CO}_{2} \mathrm{~mol}^{-1}$ ) increased the susceptibility of maize to Fusarium verticillioides proliferation although fumonisin B1 mycotoxin production was not affected. They showed that inoculation at silking the accumulation of sugars, free fatty acids, lipoxygenase transcripts, phytohormones, and downstream phytoalexins were reduced in the maize grown at elevated $\mathrm{CO}_{2}$ conditions. Further studies using this approach are required where maize is grown under such conditions and then examining the host-pathogen interaction under the climate change scenarios described here.

Abdel-Hadi et al. (2012) with the aim of forecasting the $\mathrm{AFB}_{1}$ production by Aspergillus flavus examined the integration of growth, gene expression of multiple aflatoxin genes and $\mathrm{AFB}_{1}$ production by using a mixed secondary metabolite model. This model was validated at 37 and $40^{\circ} \mathrm{C}$ and different water stress levels and predicted $\mathrm{AFB}_{1}$ production at $37^{\circ} \mathrm{C}$ under water stress conditions, but none at $40^{\circ} \mathrm{C}$. However, $\mathrm{CO}_{2}$ was not included in this model. The results obtained suggest that this model could be extended to include $\mathrm{CO}_{2}$ as a parameter and that this could be a very interesting tool to help in predicting the impact of climate change scenarios with experimental data sets as opposed to being based on historical data sets. This would be beneficial in quantifying impacts of climate change scenarios on economically important staple food crops.

There are some examples of previous studies using data on drought stress $\times$ temperature effects on A. flavus to predict impacts of interacting environmental factors. Work by Chauhan et al. $(2008,2010)$ demonstrated that it is possible to utilize an Agricultural Production Systems Simulator to calculate an Aflatoxin Risk Index (ARI) in both maize and peanuts in Australia. For maize they related seasonal temperature and soil moisture during the critical silking period to determine the ARI. They showed that both dry and hot climates made maize prone to a much higher aflatoxin contamination risk. For peanuts, they used the fractional amounts of available soil water during the crucial pod-filling period to determine the ARI. This showed that historically there has been an increase in aflatoxin contamination of peanuts in Australia related to increases in ambient temperature and decreases in rainfall. This has been developed into a web-interface tool for practically real-time use of this model. This approach is very valuable to predict low and high risk years in relation to climatic fluxes and may have application in West Africa where maize is also an important staple crop. However, these models may need modification to provide accurate predictions under climate change scenarios. Recently, Battilani et al. (2013) developed a mechanistic weather-driven model based on the infection cycle of $A$. flavus on maize to predict the risk of aflatoxin contamination in field on a daily basis from silk emergence to harvest. This included a probability index to exceed the legal limit of $5 \mu \mathrm{g} / \mathrm{kg}$ maize for aflatoxin. They suggested that this approach can be used for prediction of $A$. flavus infection and aflatoxin contamination during the growing season and at harvest. It may be possible to input the type of data from the present study to make this approach more accurate and improve the predictions of relative risk to take account of climate changes. 
Many of the recent reviews which have examined aspects of the impact of climate change have focused on plant breeding, plant diseases and mycotoxins in Europe, Australia, Africa, and the USA (Boken et al., 2008; Chauhan et al., 2008, 2010; Wu et al., 2011). These have predominantly examined the existing or historical information and tools relevant to the impacts on crop yield, the impact of drought episodes and lack of water or elevated temperatures. Magan et al. (2011) examined the impacts of $\mathrm{a}_{\mathrm{w}} \times$ temperature stress on potential changes in mycotoxin production when the temperature is changed by +3 and $+5^{\circ} \mathrm{C}$ and under different water stress regimes. Other reviews have used this same data (Paterson and Lima, 2010, 2011, 2012) to make their prediction of potential impacts. However, these previous studies did not include the three way interactions between $\mathrm{a}_{\mathrm{w}} \times$ temperature $\times$ elevated $\mathrm{CO}_{2}$. The laboratory based studies now available and those being done in FACE based systems need to be combined to be able to obtain more accurate information which can be used to predict on a regional basis the real impact that climate change scenarios may have on exposure to aflatoxins. This is especially important in at risk regions such as parts of Africa and Asia where the risks of exposure may increase under these predicted climate change conditions and threaten food security.

\section{REFERENCES}

Abdel-Hadi, A., Carter, D., and Magan, N. (2010). Temporal monitoring of the nor1 (aflD) gene of Aspergillus flavus in relation to aflatoxin B1 production during storage of peanuts under different environmental conditions. J. Appl. Microbiol. 109, 1914-1922. doi: 10.1111/j.1365-2672.2010.04820.x

Abdel-Hadi, A., Schmidt-Heydt, M., Parra, R., Geisen, R., and Magan, N. (2012). A systems approach to model the relationship between aflatoxin gene cluster expression, environmental factors, growth and toxin production by Aspergillus flavus. J. R. Soc. Interface 9, 757-767. doi: 10.1098/rsif.2011.0482

Battilani, P., Camardo Leggieri, M., Rossi, V., and Giorni, P. (2013). AFLAmaize, a mechanistic model for Aspergillus flavus infection and aflatoxin B1 contamination in maize. J. Comp. Electron. Agric. 94, 38-46. doi: 10.1016/j.compag.2013.03.005

Bebber, D. P., Ramotowski, M. A. T., and Gurr, S. J. (2013). Crop pests and pathogens move poleward in a warming world. Nat. Clim. Change 3, 985-988. doi: $10.1038 /$ nclimate 1990

Boken, V. K., Hoogenboom, G., Williams, J. H., Diarra, B., Dione, S., and Easson, G. L. (2008). Monitoring peanut contamination in Mali (Africa) using the AVHRR satellite data and a crop simulation model. Int. J. Remote Sens. 29, 117-129. doi: 10.1080/01431160701264250

Chauhan, Y. S., Wright, G. C., and Rachaputi, N. C. (2008). Modelling climatic risks of aflatoxin contamination in maize. Aust. J. Exper. Agric. 48, 358-366. doi: 10.1071/EA06101

Chauhan, Y. S., Wright, G. C., Rachaputi, R. C. N., Holzworth, D., Broome, A., Krosch, S., et al. (2010). Application of a model to assess aflatoxin risk in peanuts. J. Agric. Sci. 148, 341-351. doi: 10.1017/S002185961000002X

Dobolyi, C. S., Sebok, F., Varga, J., Kocsube, S., Szigeti, G., Baranyi, N., et al. (2013). Occurrence of aflatoxin producing Aspergillus flavus isolates in maize kernels in Hungary. Acta Alimentria 42, 451-459. doi: 10.1556/AAlim.42.2013.3.18

European Commission. (2006). Commission Regulation 1881/2006 of 19 December, 2-006. Setting maximum levels for certain contaminants in food stuffs. Off. J. Eur. Union L 364, 5-24.

European Commission (2007). Adapting to climate change in Europe - options for, EU action. Green paper from the Commission to the Council, the European, Parliament, the European, Economic and Social Committee of the Regions, COM. (2007). 254 final, SEC (2007) 849. European Commission Brussels.

Giorni, P., Magan, N., Pietri, A., Bertuzzi, T., and Battilani, P. (2007). Studies on Aspergillus Section Flavi isolated in northern Italy from maize. Int. J. Food Microbiol. 113, 330-338. doi: 10.1016/j.ijfoodmicro.2006.09.007

Hayes, B. M. E., Anderson, M. A., Traven, A., van der Weerden, N. L., and Bleackley, M. R. (2014). Activation of stress signalling pathways enhances tolerance of fungi to chemical fungicides and antifungal proteins. Cell. Mol. Life Sci. 71, 2651-2666. doi: 10.1007/s00018-014-1573-8

IARC. (2012). Agents Classified by the IARC Monographs. Vol. 1e104. International Agency for Research on Cancer. Available online at: http://monographs.iarc.fr/ ENG/Classification/index.php

IPCC. (2007). "Intergovernmental panel on climate change report. Climate Change 2007," in Synthesis Report (Geneva), 52.

Kos, J., Mstilovic, J., Hajnal, E. J., and Saric, B. (2013). Natural occurrence of aflatoxins in maize harvested in Serbia during 2009-2012. Food Control 34, 31-34. doi: 10.1016/j.foodcont.2013.04.004

Leong, S., Pettersson, O. V., Rice, T., Hocking, A. D., and Schnurer, J. (2010). The extreme xerophilic mould Xeromyces bisporus - growth and competition at various water activities. Int. J. Food Microbiol. 145, 57-63. doi 10.1016/j.ijfoodmicro.2010.11.025

Lewis, L., Onsongo, M., Njapau, H., Schurz-Rogers, H., Luber, G., Kieszak, S., et al. (2005). Aflatoxin contamination of commercial maize products during an outbreak of acute aflatoxicosis in eastern and central Kenya. Environ. Health Perspect. 113, 1763-1767. doi: 10.1289/ehp.7998

Magan, N. (2006). Mycotoxin contamination of food in Europe: early detection and prevention strategies. Mycopathologia 162, 245-253. doi: 10.1007/s11046006-0057-2

Magan, N., and Aldred, D. (2007). Post-harvest control strategies: minimizing mycotoxins in the food chain. Int. J. Food Microbiol. 119, 131-139. doi: 10.1016/j.ijfoodmicro.2007.07.034

Magan, N., Aldred, D., Hope, R., and Mitchell, D. (2010). Environmental factors and interactions with mycoflora of grain and grapes: effects on growth and deoxynivalenol and ochratoxin production by Fusarium culmorum and Aspergillus carbonarius. Toxins 2, 353-366. doi: 10.3390/toxins 2030353

Magan, N., Medina, A., and Aldred, D. (2011). Possible climate change effects on mycotoxin contamination of food crops pre- and post-harvest. Plant Pathol. 60, 150-163. doi: 10.1111/j.1365-3059.2010.02412.x

Medina, A., Rodriguez, A., and Magan, N. (in press). Climate change factors and A. flavus: effects on gene expression, growth and aflatoxin production. World Mycotoxin J.

Medina, A., Schmidt-Heydt, M., Cárdenas-Chávez, D. L., Parra, R., Geisen, R., and Magan, N. (2013). Integrating toxin gene expression, growth and fumonisin B1 and B2 production by a strain of Fusarium verticillioides under different environmental factors. J. R. Soc. Interface 10, 20130320. doi: 10.1098/rsif.2013.0320

Miraglia, M., Marvin, H. J. P., Kleter, G. A., Battilani, P., Brera, C., Coni, E., et al. (2009). Climate change and food safety: an emerging issue with special focus on Europe. Food Chem. Toxicol. 47, 1009-1021. doi: 10.1016/j.fct.2009.02.005

Paterson, R., and Lima, N. (2010). How will climate change affect mycotoxins in food? Food Res. Int. 43, 1902-1914. doi: 10.1016/j.foodres.2009.07.010

Paterson, R., and Lima, N. (2011). Further mycotoxin effects from climate change. Food Res. Int. 44, 2555-2566. doi: 10.1016/j.foodres.2011.05.038

Paterson, R., and Lima, N. (2012). "Climate change, fumonisins and animal feed," in Nutrieconomics: Balancing Global Nutrition and Productivity, ed E. M. Binder (Tulln: Biomin World Nutrition Forum), 241-247.

Piecková E., and Kunová Z. (2002). Indoor fungi and their ciliostatic metabolites. Ann. Agric. Environ. Med. 9, 59-63.

Sanchis, V., and Magan, N. (2004). "Environmental profiles for growth and mycotoxin production, Chapter 8," in Mycotoxins in Food: Detection and Control, eds N. Magan and M. Olsen (Cambridge, MA: Woodhead Publishing Ltd.), 174-189.

Schmidt-Heydt, M., Abdel-Hadi, A., Magan, N., and Geisen, R. (2009). Complex regulation of the aflatoxin biosynthesis gene cluster of $A$. flavus in relation to various combinations of water activity and temperature. Int. J. Food Microbiol. 135, 231-237. doi: 10.1016/j.ijfoodmicro.2009.07.026

Schmidt-Heydt, M., and Geisen, R. (2007). A microarray for monitoring the production of mycotoxins in food. Int. J. Food Microbiol. 117, 131-140. doi: 10.1016/j.ijfoodmicro.2007.01.014

Schmidt-Heydt, M., Magan, N., and Geisen, R. (2008). Stress induction of mycotoxin biosynthesis genes in relation to abiotic factors. FEMS Microbiol. Lett. 284, 142-149. doi: 10.1111/j.1574-6968.2008.01182.x

Schmidt-Heydt, M., Parra, R., Geisen, R., and Magan, N. (2011). Modelling the relationship between environmental factors, transcriptional genes and deoxynivalenol mycotoxin production by two Fusarium species. J. Royal Soc. Interface 8, 117-126. doi: 10.1098/rsif.2010.0131 
Schmidt-Heydt, M., Rüfer, C. E., Abdel-Hadi, A., Magan, N., and Geisen, R. (2010). The production of aflatoxin B1 or G1 by Aspergillus parasiticus at various combinations of temperature and water activity is related to the ratio of aflS to aflR expression. Mycotoxin Res. 26, 241-246. doi: 10.1007/s12550-0100062-7

Solomon, S., Quin, D., Manning, M., Alley, R. B., Berstein, T., Bindoff, N. I., et al. (2007). "Technical summary," in Climate Change 2007: The Physical Science Basis. Contribution of Working Group 1 to the Fourth Assessment Report of the Intergovernmental Panel on Climate Change, eds S. Solomon, D. Quin, M. Manning, Z. Chen, M. Marquis, K. B. Averyt, M. Tignor and H. L. Miller (Cambridge, NY: Cambridge University Press), 996.

Vaughan, M. M., Huffaker, A., Schmelz, E. A., Dafoe, N. J., Christensen, S., Sims, J., et al. (2014). Effects of elevated [CO2] on maize defence against mycotoxigenic Fusarium verticiilioides. Plant Cell Environ. doi: 10.1111/pce. 12337. [Epub ahead of print].

Wagacha, J. M., and Muthomi, J. W. (2008). Mycotoxin problem in Africa: current status, implications to food safety and health and possible management strategies. Int. J. Food Microbiol. 124, 1-12. doi: 10.1016/j.ijfoodmicro.2008.01.008

Wu, F., Bhatnagar, D., Bui-Klimke, T., Carbone, I., Hellmich, R., Munkvold, G., et al. (2011). Climate change impacts on mycotoxin risks in US maize. World Mycotoxin J. 4, 79-93. doi: 10.3920/WMJ2010.1246

Yu, J., Chang, J. W., Wright, M., Bhatnagar, D., Cleveland, T. E., Payne, G. A., et al. (1995). Comparative mapping of aflatoxin pathway gene clusters in Aspergillus parasiticus and Aspergillus flavus. Appl. Environ. Microbiol. 61, 2365-2371.
Yu, J., Chang, P.-K., Ehrlich, K. C., Cary, J. W., Bhatnagar, D., Cleveland, T. E., et al. (2004). Clustered pathway genes in aflatoxin biosynthesis. Appl. Environ. Microbiol. 70, 1253-1262. doi: 10.1128/AEM.70.3.1253-1262.2004

Yu, J., Fedorova, N. D., Montalbano, B. G., and Bhatnagar, D. (2011). Tight control of mycotoxin biosynthesis gene expression in Aspergillus flavus by temperature as revealed by RNA-Seq. FEMS Microbiol. Lett. 322, 145-149. doi: 10.1111/j.1574-6968.2011.02345.x

Conflict of Interest Statement: The authors declare that the research was conducted in the absence of any commercial or financial relationships that could be construed as a potential conflict of interest.

Received: 29 May 2014; accepted: 23 June 2014; published online: 22 July 2014.

Citation: Medina A, Rodriguez A and Magan N (2014) Effect of climate change on Aspergillus flavus and aflatoxin $B_{1}$ production. Front. Microbiol. 5:348. doi: 10.3389/ fmicb. 2014.00348

This article was submitted to Food Microbiology, a section of the journal Frontiers in Microbiology.

Copyright (C) 2014 Medina, Rodriguez and Magan. This is an open-access article distributed under the terms of the Creative Commons Attribution License (CC BY). The use, distribution or reproduction in other forums is permitted, provided the original author(s) or licensor are credited and that the original publication in this journal is cited, in accordance with accepted academic practice. No use, distribution or reproduction is permitted which does not comply with these terms. 